\title{
Ethics In The Accounting Curriculum: What Is Really Being Covered?
}

William F. Miller, University of Wisconsin, Eau Claire, USA

D’Arcy A. Becker, University of Wisconsin, Eau Claire, USA

\begin{abstract}
This paper examines the current level of ethics integration across the accounting curriculum, analyzing the quantity, methods and topics included in coverage. Results of a survey of U.S. accounting faculty from 44 states and 97 different institutions on these issues are presented. The study is broken into two sections: the actual level of ethics integration and what is actually being taught. Prior research in the field has been limited to the extent to which ethics is covered in the classroom and avoided looking at what specifically is being done. This study extends this research by providing an update on the level of coverage as it exists today in the U.S., and by identifying the specific ethics topics being covered. Overall, we find that ethics integration efforts on a per-course basis are modest, and may be inadequate. We suggest that accounting programs that integrate ethics develop a formal ethics integration plan to ensure essential topics are covered, and to maximize the impact on students' ethics.
\end{abstract}

Keywords: Accounting Ethics; Accounting Curriculum; AACSB; Ethics Integration

\section{INTRODUCTION}

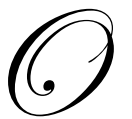

ne driving force behind The Sarbanes-Oxley Act of 2002 (SOX) was to give the U.S. government the power to deter ethical lapses by accountants. Accountants were targeted for having failed to detect and report frauds quickly, with possible financial motives such as earning high consulting fees from audit clients as one suspected cause. CEOs and CFOs were targeted for having their employees commit fraud seemingly in open view while top management claimed no knowledge of the unethical activities.

As the recent resurgence in unethical conduct suggests, SOX may have had a very limited effect on accountants' ethics. Although SOX placed significant limitations on CPAs' activities, none of the recent fraud cases resulted from violations of those additional regulations. It is not that SOX fails to regulate important CPA activities, it is just that those regulations fail to address the underlying cause of ethical failures: personal ethics. To be considered ethical leaders, executives must be both moral persons and moral managers (AACSB, 2004).

Improving the level of individual accountants' ethics may be the most effective way to improve business ethics. The threat of fines, loss of a professional license or imprisonment may have a deterrent effect for some, but these methods clearly have not been completely effective. It may be through education rather than government regulation that ethics in the accounting profession will improve.

Our study investigates the current state of ethics coverage in accounting curricula across the U.S. We surveyed accounting faculty to determine how much coverage actually exists and determine which topics are included in that coverage. Prior research has not investigated specific topics covered on a broad scale across U.S. accounting programs, nor has it investigated the amount of time devoted to that coverage.

Overall, we find that ethics integration efforts on a per-course basis are modest, and may be inadequate. We suggest that accounting programs that integrate ethics develop a formal ethics integration plan to ensure essential topics are covered, and to maximize the impact on students' ethics. 


\section{PRIOR LITERATURE}

A 2009 PriceWaterhouseCoopers survey of 3,000 senior executives from 54 countries found that global corporate accounting fraud is on the rise again, and accounting fraud was 38\% of the economic crimes in 2009 (PWC, 2009). Recent cases like Satyam, Madoff and Lehman Brothers are all giant frauds that involve accounting and auditing failures as well as other criminal activity. Clearly, the state of ethics in the accounting profession remains below acceptable levels.

Few college accounting programs have undertaken serious efforts to improve accounting student ethics. College and university accounting programs have not significantly changed their methods of instruction or approach to accounting and management education over the last 50-60 years (Russell and Smith, 2003). The U.S. is not alone in having failed to respond to these corporate failures with educational changes. Noel and Trebucq (2005) report that European business schools have also failed to make substantial adjustments to ethics training for future accountants.

The AICPA and nearly all countries' accounting licensing bodies allow each program to determine how best to provide its students with ethics education, believing all methods can provide adequate ethics training. Licensing exam requirements drive an array of approaches to teaching ethics to undergraduates around the world. For example, Australia's CPA exam has a full section on Ethics and Governance and also tests ethics knowledge in the Contemporary Business Issues section. The Australian Teaching \& Learning Council has publicized a wide array of opportunities for accounting programs to integrate ethics coverage in various courses (Hancock, Howieson, Kavanagh, Kent, Tempone and Segal, 2009). Indeed, business schools in every country have developed engaging, innovative strategies for teaching ethics.

However, the assumption that the majority of students are being adequately prepared to address complex ethical issues is difficult to support (AACSB, 2004). One reason is that most research on ethical development shows that individuals attain their highest form of moral and ethical reasoning sometime in their late 30's (Frank, Ofobike and Gradisher, 2010). Therefore, ethics education may be very effective but its impact may not be evident until graduates are in the middle of their careers. Conversely, if ethics education is ineffective, that fact also may be difficult to determine on a timely basis.

Prior research on ethics education for accounting students addresses many topics including whether or not ethics can be taught (e.g. Geary and Sims, 1994), how best to teach it in terms of methodology and approach (e.g. Massey and Van Hise, 2009) and the level at which ethics is being integrated into accounting curriculum (e.g. McNair and Milam, 1993; Fisher, Blanthorne and Kovar, 2007; Ghaffari, Kyriacou and Brennan, 2008), among other areas.

Accounting professors continue to believe ethics coverage is important. For example, Armitage and Poyzer (2010) compare the views of practitioners and accounting professors concerning auditing course coverage, including the importance of ethics. Although neither group rated ethics as the most important element in an auditing course, both had ethics as one of the top 5 most important topics.

There are generally two main choices for programs wishing to add ethics to the curriculum: teach ethics in a stand-alone class or integrate ethics throughout the curriculum. The concept behind integration is that existing accounting classes can replace some content with ethics content, thereby adding the content without hiring new faculty or displacing entire existing courses.

The relative effectiveness of each implementation method has been the focus of a broad set of research, and opinions abound about the benefits on each side. For example, Adkins and Radtke (2004) argue that stand-alone courses make ethics prominent in the minds of students, while Oddo (1997) argues that stand alone classes inhibit students' ability to apply ethics across many contexts.

Integrating ethics coverage across the accounting curriculum was championed years ago by the Bedford Commission, the Treadway Commission and the AACSB (Windsor, 2002). When the AACSB began promoting the integration model in 1991, most schools had been using standalone ethics courses to meet accreditation requirements 
(Windsor, 2002). At the time, there was general dissatisfaction with the failure of faculty to show student ethics had improved as a result of the courses. The AACSB adopted the widely-accepted view that students needed to hear information about ethics throughout their curriculum in order to advance their ethical decision making to a high level. The quality of ethics knowledge achieved when either separate courses are taught or the integration model is used has not been definitively established.

Resource limitations and unwillingness to displace traditional accounting courses, among other factors, have led separate courses in ethics to become the exception rather than the rule in accounting curricula. Unless mandated by state CPA societies (e.g. Texas) to provide separate ethics courses, schools have opted for the integrated model. Several studies have attributed the dramatic decrease in stand-alone ethics courses being offered over the past decade, and in the overall quality of the ethics curriculum being offered, to the change in policy by the AACSB (e.g. Fisher, Swanson and Schmidt, 2005; Trank and Rynes, 2003; Waddock, 2005).

Whether coverage is delivered in a single course or across the curriculum, it is the content of the coverage that matters most. Some prior research has investigated ethics coverage in the accounting curriculum. For example, Madison and Schmidt (2006) asked department chairs about the level of coverage they thought existed in their programs and whether that coverage was at an appropriate level; they did not directly ask faculty about ethics coverage. Ghaffari, Kyriacou and Brennan (2008) conducted a similar survey of accounting programs in the U.K. which was limited to the question of integration versus stand alone coverage.

The AACSB's Ethics Education Task Force (AACSB, 2004) issued a report providing guidance surrounding the topics they believe to be essential to fulfilling business schools' educational responsibilities of producing the ethical leaders of the future. This report did not mandate the precise topics to be covered, but it did provide categories of ethics coverage that could be considered when evaluating whether schools meet accreditation standards in relation to ethics education. The task force provided substantial flexibility to schools as a means of encouraging educators to develop new ways of incorporating ethics across the curriculum.

Ethics coverage has not progressed to the point of effectively helping students develop more sound moral reasoning, in part because of how accounting educators implement the coverage (Frank, Ofobike and Gradisher, 2010). Our study investigates how ethics is covered by determining both time spent on ethics and which specific ethics topics are covered. Time spent can significantly impact the effectiveness of ethics coverage. If coverage is spread too thinly across courses, its impact is lost. If coverage is too heavy, students will tune it out because they feel they already know the content. In addition, if topics are not covered in a logical, coherent order, their value in improving student ethics may be lost.

\section{THE SURVEY}

We surveyed 1200 accounting faculty members from state universities across the U.S. about their overall attitude about teaching ethics, the overall level of coverage of ethics within their accounting curriculum, the ethics related topics they cover and the time dedicated to each topic. The survey was conducted electronically over a period of six weeks, with one reminder sent out mid-way through the survey period. Two orders of the survey questions were used. Some responses were made on a 5-point Likert scale (Strongly Agree - Strongly Disagree); other formats of questions were also used as explained below.

We investigated respondents' overall attitudes about teaching ethics. We asked whether they think ethics should be taught and in what way (integrated or not), and whether their school's personnel evaluation system includes evaluation of ethics integration. These attitudes could be important drivers of the nature of ethics education being provided. Figure 1 shows the six questions asked on this issue.

In addition, we sought to determine the overall quantity of ethics coverage and to identify time spent on specific topics identified by the literature and the AACSB as being essential to developing future ethical business leaders. The amount of time devoted to ethics has implications for how the topics are covered. It also sends a signal about the value the instructor places on the content. Questions related to these issues are shown in Figure 2 below. 


\section{Figure 1}

Overall Attitudes toward Ethics in the Accounting Curriculum

1. I believe ethics should be taught

2. I have integrated ethics into my accounting curriculum

3. I believe that ethics should be integrated into the accounting curriculum

4. The administration of my university supports the integration of ethics into the accounting curriculum

5. I am incented to integrate ethics into my curriculum

6. Part of what I am formally evaluated on is based on my integration of ethics into my curriculum

1. Does your school have

Figure 2

\section{Nature of Ethics Coverage}

a. A separate course in business ethics that is required of accounting majors?

b. A separate course in business ethics that is an elective for accounting majors?

c. A separate course in accounting ethics that is required of accounting majors?

d. A separate course in accounting ethics that is an elective for accounting majors?

2. In aggregate, the $\%$ of coverage I give to ethics in my undergraduate accounting courses (as compared to everything else I cover) is approximately $\%$ ?

3. If and when ethics is covered in my undergraduate accounting courses, the following \%'s apply to the topics covered (the total should equal $100 \%$ ).

a.___ Role of accounting in society

b. __ Defining ethics

c. __ Right versus Wrong

d. Ethical theories

e. Identifying ethical issues

f. ___ Evaluating ethical issues

g.___ Resolving ethical issues

h.___ Using critical thought, analysis and judgment

i. __ Other

\section{SURVEY RESPONDENTS}

235 faculty members from 97 different universities (and 44 states) replied to the survey, for an overall response rate of $19.6 \%$. Of those responses, 232 were usable. Respondents represent a broad set of U.S. accounting faculty: $89 \%$ are from AACSB accredited schools; the gender split is $59 \%$ male and $41 \%$ female; primary teaching responsibilities are shown in Table 1. All major teaching areas of accounting are represented.

Table 1

Respondent Primary Teaching Responsibilities

\begin{tabular}{|l|l|}
\hline Introductory Financial Accounting & $25 \%$ \\
\hline Advanced Financial Accounting & $18 \%$ \\
\hline Auditing & $15 \%$ \\
\hline Intermediate/Cost/Tax & $42 \%$ \\
\hline
\end{tabular}

As shown in Table 2 (below), respondents had significant teaching experience as well as significant professional accounting experience. The sample represents a broad array of experience. 
Table 2

Survey Respondent Work Experience

\begin{tabular}{|l|c|c|}
\hline \multicolumn{1}{|c|}{ Level of Experience } & Teaching & Professional Accounting \\
\hline Less than 5 years & $16 \%$ & $50 \%$ \\
\hline Between 5 and 10 years & $16 \%$ & $20 \%$ \\
\hline Between 10 and 15 years & $10 \%$ & $13 \%$ \\
\hline Over 15 years & $57 \%$ & $17 \%$ \\
\hline
\end{tabular}

\section{SURVEY RESULTS - OVERALL ATTITUDE TOWARD TEACHING ETHICS}

The first step in examining ethics instruction is to determine whether respondents believe ethics should be taught. Clearly, faculty will not include content in their classes if they do not believe the content is appropriate. Prior literature shows that there is general agreement that ethics training should be provided in undergraduate accounting programs as a means of moving students further along the ethical development continuum (Blanthorne, Kovar and Fisher, 2007; Galbraith and Webb, 2010).

Our results are consistent with prior studies showing faculty support teaching ethics; $78 \%$ of our respondents believe that ethics should be taught. However, this is a decrease from the very high level of support (95\%) reported in Fisher, Blanthorne and Kovar (2007) and Madison and Schmidt (2006).

We also found substantial commitment to integrating ethics across the accounting curriculum; $87 \%$ of respondents support the concept. This is an increase from 70\% reported in by Madison \& Schmidt, (2006) and $35 \%$ reported by McNair and Milam (2003). This increase may be due to AACSB requirements regarding teaching ethics. Given the reality of having to cover ethics in some manner, most schools logically choose to integrate across their curricula rather than devoting new resources to stand-alone courses.

Support for ethics integration extends to administrators; $78 \%$ of respondents felt their school's administration supports the concept. However, important signals about the level of that support are not encouraging. Only $24 \%$ of respondents report having incentives to integrate ethics, and a mere $7 \%$ report that including ethics in their curriculum impacts their personnel evaluation. Clearly, actions on the part of administrators could be strengthened.

\section{SURVEY RESULTS - HOW ETHICS IS COVERED}

A high rate of faculty agreed that ethics should be taught and support teaching it across the curriculum rather than in a single course. We found that faculty actions have followed this preference. $79 \%$ of respondents reported they have integrated ethics coverage into their accounting curriculum. This is significantly higher than the $50 \%$ of faculty who reported they had integrated ethics in 2007 (Fisher, Blanthorne and Kovar, 2007). It also compares favorably with a U.K. survey indicating an integration level of $75.9 \%$ conducted by Ghaffari, Kyriacou and Brennan (2008).

Table 3

Are Separate Ethics Courses Available?

\begin{tabular}{|l|c|c|c|}
\hline \multicolumn{1}{|c|}{ Ethics Courses Offered } & $\begin{array}{c}\text { Is Required for all } \\
\text { Accounting Majors }\end{array}$ & $\begin{array}{c}\text { Is an Elective for All } \\
\text { Accounting Majors }\end{array}$ & $\begin{array}{c}\text { No separate ethics } \\
\text { Courses are Offered }\end{array}$ \\
\hline A separate course in Business Ethics & $19.39 \%$ & $30.10 \%$ & $50.51 \%$ \\
\hline A separate course in Accounting Ethics & $13.85 \%$ & $11.28 \%$ & $74.87 \%$ \\
\hline
\end{tabular}

Because faculty believe ethics content should be integrated, and most report having undertaken significant effort to integrate ethics, it is logical that respondents would report offering few separate ethics courses. Table 3 (above) confirms the low rate of separate ethics courses respondents have made available to their students. $50 \%$ of respondents' programs have no separate ethics course in their curriculum, leaving integrating ethics content as the only option. 
Our survey also asked about the amount of time spent teaching ethics topics as another way to determine the level of faculty commitment to integrating ethics in their courses. The time available in each course is fixed, so adding ethics coverage means deleting other topics. We found that the average level of coverage of all ethics topics in a course was $9 \%$ of the course, or about 3.4 hours (or about one week). This is similar to 3.18 hours reported by McNair and Milam (1993), 3.8 hours reported by Cole (2003), and 4 hours reported by Fisher, Blanthorne and Kovar (2007). The overall level of ethics coverage does not appear to have changed significantly in 17 years.

The strength and nature of support for integrating ethics remains an open question. Many respondents say they support integrating ethics, and this is supported by the fact that their schools offer no separate ethics courses. However, the volume of ethics coverage is low.

\section{SURVEY RESULTS - WHAT IS INCLUDED IN ETHICS CONTENT}

In addition to time spent overall, we asked about faculty coverage of a specific set of ethics topics. Our list of topics comes from the categories of coverage suggested by the AACSB (2004) report: responsibility of business in society; ethical leadership and, ethical decision making. We asked specifically about the individual elements of each category; topics in our survey are shown in Table 4 (below).

Responsibility of Business in Society addresses the need for students to understand the interdependence between business and society and more specifically the role of professions in society. This category addresses the need for students to understand the power that businesses yield and how their actions (and the decisions they make) can positively or negatively impact stakeholders, including society at large. The accounting profession plays an important role in not only the operation of a business, but with public accounting as the watchdog of the public trust. The teaching of the Role of Accounting to Society is therefore a critical component of the ethics curriculum for accounting students.

As a result, we asked if the role of accounting to society (item \#1) was a part of the ethics coverage in the accounting courses they teach. We found 145 respondents spend some time on this topic, and the average time is 25 minutes, about half of one class.

Ethical Leadership addresses the need for students to become ethical managers within organizations. Relevant topics should provide students with a framework upon which knowledge of ethical decisions can be built: what ethics is (item \#2), the theories surrounding it (item \#4), and decision making models/frameworks (item \#5). We added 'right versus wrong' (item \#3) to this list because this simplistic view of ethics is common, lay language used to refer to ethics.

In general, respondents reported spending some time on defining ethics (114 respondents) and right versus wrong (106). However, significantly fewer respondents spend time on ethics theories (71) and decision making models (84). Failure to cover these basic concepts may end up inhibiting growth in students' ethical reasoning. It is analogous to failing to cover debits and credits in early courses in financial accounting, covering advanced topics instead. Without this building block knowledge, students cannot successfully understand more advanced concepts (e.g. Fisher, Swanson and Schmidt, 2005).

Ethical Decision Making addresses the need for students to be able to identify, evaluate and resolve ethical issues. It includes the complex nature of ethical decisions and the need for students to be able to think critically, analyze complex problems and use their own judgment to choose a course of action. We asked about these topics related to ethical decision making: identifying ethical issues (item \#6), evaluating ethical issues (item \#7), resolving ethical issues (item \#8) and using critical thought, analysis and judgment (item \#9) as a part of the coverage of ethics in the accounting courses they teach.

We found that these are the most heavily covered topics on our list. Identifying ethical issues was covered by more respondents (179) than any other topic, followed by evaluating ethical issues (166), using critical thought, analysis and judgment (163), and resolving ethical issues (150). 
Table 4

Allocation of Ethics Coverage Across Ethics Topics in each Course

\begin{tabular}{|l|c|c|c|}
\hline \multicolumn{1}{|c|}{ Ethics Topic } & $\begin{array}{c}\text { \# with any level of } \\
\text { coverage }\end{array}$ & $\begin{array}{c}\text { Average Percent of } \\
\text { Ethics Coverage } \\
\text { devoted to topic }\end{array}$ & $\begin{array}{c}\text { Average \# of Minutes } \\
\text { Spent on Topic }\end{array}$ \\
\hline 1. Role of Accounting in Society & 145 & $12 \%$ & 25 \\
\hline 2. Defining Ethics & 114 & $7 \%$ & 14 \\
\hline 3. Right versus Wrong & 106 & $10 \%$ & 20 \\
\hline 4. Ethical Theories & 71 & $4 \%$ & 8 \\
\hline 5. Decision Making Models & 84 & $5 \%$ & 11 \\
\hline 6. Identification of Ethical Issues & 179 & $18 \%$ & 36 \\
\hline 7. Evaluating Ethical Issues & 166 & $15 \%$ & 30 \\
\hline 8. Resolving Ethical Issues & 150 & $11 \%$ & 23 \\
\hline 9. Using Critical Thought, Analysis, Judgment & 163 & $16 \%$ & 33 \\
\hline 10. Other & 16 & $2 \%$ & \\
\hline
\end{tabular}

As shown in the last column of Table 4, the number of minutes spent in any one class on these ethics topics is quite modest. The average respondent covered 5 of the topics in Table 4 . When ethics is covered, most respondents cover topics related to ethical decision making, followed closely by the role of business in society. Most fail to address any topics contained in the foundational category of Ethical Leadership.

\section{CONCLUSIONS AND IMPLICATIONS}

The level of ethics coverage reported by accounting faculty in our study is somewhat modest on a percourse basis (about one week per course), but when viewed across the entire accounting curriculum the time spent on ethics would be adequate if it is used wisely.

A more important issue than raw time spent teaching ethics is what is included in that coverage. Our results imply integrating ethics in the accounting curriculum can be done more effectively if coverage is coordinated. Nearly all of our respondents claim to use integrated coverage, but what they meant by integration was more an ad hoc list of topics that is implemented as a collection of topics rather than as a synchronized set of topics that build student knowledge.

The topics included in our survey are diverse in nature and size and we did not expect every respondent to cover them all. However, we were surprised that there seemed to be a substantial lack of coverage of foundational topics such as how to define ethics, ethical theories and ethics decision making models. Students may not be able to learn ethics unless they start with fundamental topics such as those in the ethical leadership category (Fisher, Swanson and Schmidt, 2005).

The timing of ethics coverage across the curriculum would ideally emerge from a comprehensive ethics integration plan. Accounting curricula routinely coordinate financial accounting coverage (and all accounting content); ethics coverage should be treated in the same way.

One possible barrier to getting faculty to coordinate ethics coverage is a bias against covering ethics. Whereas $100 \%$ of accounting faculty support covering financial accounting (and other accounting topics), we found only $79 \%$ supported covering ethics. Without the cooperation of the last $21 \%$ of the faculty, an integrated plan is unlikely to be successful.

Another barrier to integration is a lack of institutional support for the extra work it causes for faculty. We found very few schools back ethics by overtly providing financial (or other) incentives to expand this area of their curriculum. AACSB may further exacerbate this problem by accrediting schools that give lip service to integrating ethics coverage but do not make a sincere and coordinated effort to do so. 
At the most basic level, a plan to integrate ethics across the curriculum would include 1) the entire set of topics to be covered including foundational knowledge, 2) logical ordering of the content to ensure students experience ethics topics building on each other under different course sequencing scenarios, and 3) the time commitment necessary to cover the various content elements.

Research in this area can expand our understanding of how different elements in an integrated ethics plan can be combined most effectively. Some accounting courses already have ethics content (e.g. auditing) while others may not. Deciding which courses should replace traditional accounting content with ethics depends on many factors including faculty preference, faculty training, the number of faculty teaching accounting, the number and nature of accounting electives and university-wide requirements, among others. Research that provides some clarity on how those factors combine to create an effective ethics education would be helpful.

More research should also be done regarding teaching ethics to accounting students in other countries. Our study focused on what is being done in U.S. universities. Perhaps U.S. universities are leading the way in covering ethics, and perhaps they are lagging.

Lastly, more research should be done regarding what is being taught in regard to ethics throughout the entire business curriculum. Our research was limited to the accounting discipline only. Given that the AACSB's mandate was to spread the coverage of ethics throughout the overall business curriculum, there would be value in looking at the whole picture.

An ethics education cannot be prescriptive in nature (Merino, 2006). It needs to portray ethics as complex, and teach students to interpret situations and make decisions in an ethical manner. The overall goal is to help our students to think critically, and be able to recognize and resolve ethical issues across different settings (Shawver, 2006). Our responsibility as educators is to provide guidance to future business leaders to make the business future a positive environment; we help future accountants strike a balance between the future they make and the future they take (Galbraith and Webb, 2010). In order to be successful in positively impacting the personal ethics of our students, we must develop coordinated plans of action whose use is supported by accrediting and licensing bodies, accounting department members and university administration.

\section{AUTHOR INFORMATION}

Dr. William Miller, CPA is an Assistant Professor of Accounting at the University of Wisconsin - Eau Claire. Dr. Miller has extensive industry experience. His academic research interests include accounting ethics and issues related to financial accounting and International Financial Reporting Standards. His main areas of teaching include accounting ethics and financial accounting. University of Wisconsin, Eau Claire, SSS 455, Eau Claire, WI, 54702; E-mail: millerwf@uwec.edu; Phone: 715-836-5434; Fax: 715-836-3582

Dr. D'Arcy Becker, CPA is a Professor of Accounting and Chair of the Department of Accounting and Finance at the University of Wisconsin - Eau Claire. Her main expertise is in auditing, and her academic research interests include gender and ethics issues, and issues relevant to accounting education. University of Wisconsin, Eau Claire, SSS 400A, Eau Claire, WI, 54702; E-mail: dbecker@uwec.edu; Phone: 715-836-6028; Fax: 715-836-3582

\section{REFERENCES}

1. Adkins, N., and R. R. Radtke. (2004). Students' and faculty members' perceptions of the importance of business ethics and accounting ethics education: Is there an expectations gap? Journal of Business Ethics, 51: 279-300.

2. Armitage, J. and J.K. Poyzer. (2010). Academicians' and Practitioners' Views on the Importance of the Topical Content in the First Auditing Course. American Journal of Business Education, 3(1): 71-82.

3. Association to Advance Collegiate Schools of Business (AACSB) International. (2004). Ethics education in business schools: Report of the ethics education task force to AACSB International's board of directors. AACSB, St. Louis, MO'. 
4. Blanthorne, C., S.E. Kovar and D.G. Fisher. (2007). Accounting Educators' Opinions about Ethics in the Curriculum: An Extensive View. Issues in Accounting Education, 22(3): 355-390.

5. Breaux, K., M. Chiasson, S. Mauldin and T. Whitney. (2010). Ethics Education in Accounting Curricula: Does it Influence Recruiters' Hiring Decisions of Entry-Level Accountants? Journal of Education for Business, 85: 1-6.

6. Cole, C. S.. (2003). An investigative analysis of teaching business ethics in Tennessee community colleges. Eastern Tennessee State University, Dissertation: 1-132.

7. Fisher, D., C. Blanthorne and S. Kovar. (2007). Accounting educators' opinions about ethics in the curriculum: A profile. Issues in Accounting Education, 22: 355-389.

8. Fisher, D., L. Swanson and J. Schmidt. (2007). Accounting Education Lags CPE Ethics Requirements: Implications for the Profession and a Call to Action. Accounting Education, 16,4: pp. 345-363.

9. Frank, G., E. Ofobike and S. Gradisher. (2010). Teaching Business Ethics: A Quandary for Accounting Educators. Journal of Education for Business, 85: 132-138.

10. Galbraith, D. and F. Webb. (2010) Business Ethics: A View From The Classroom. Journal of College Teaching and Learning, Apr; 7,4: 39-51

11. Geary, W.T. and R.R. Sims. (1994). Can Ethics be Learned? Accounting Education, 3: 3-18.

12. Ghaffari, F., O. Kyriacou, and B. Ross. (2008). Exploring the Implementation of Ethics in U.K. Accounting Programs. Issues in Accounting Education, 23: 183-198.

13. Hancock, P., B. Howieson, M. Kavanagh, J. Kent, I. Tempone and N. Segal. (2009). Accounting for the Future: More than Numbers. Australian Teaching and Learning Council.

14. Madison, L. and J. Schmidt. (2006). Survey of Time Devoted to Ethics in Accountancy Programs in North American Colleges and Universities. Issues in Accounting Education, 21(2): 99-109.

15. Massey, D.W. and J. Van Hise. (2009). Walking the Walk: Integrating Lessons from Multiple Perspectives in the Development of an Accounting Ethics Course. Issues in Accounting Education, 24(4): $481-511$.

16. McNair, F. and E. Milam. (1993). Ethics in Accounting Education: What is Really Being Done. Journal of Business Ethics, 12: 797-809.

17. Merino, B.. (2006). Financial Scandals: Another Clarion Call for Educational Reform- A Historical Perspective. Issues in Accounting Education, 21(4): 363-381.

18. Noel, C. and S. Trebucq. (2005). Accounting Education and Business Ethics After Enron: the European Illusion. International Journal of Accounting, Auditing and Performance Evaluation, 2(4):414-430.

19. Oddo, A. R.. (1997). A Framework for teaching business ethics. Journal of Business Ethics 16(3): 293297.

20. Price Waterhouse Coopers. (2009). Global Economic Crime Survey 2009. Available via the web at http//:Www.PWC.com/crimesurvey.

21. Russell, K. and C. Smith. (2003). Accounting educations role in corporate malfeasance: It's time for a new curriculum! Strategic Finance, 85(6): 47-51.

22. Shawver, T. (2006). An exploratory study assessing the effectiveness of a professional responsibility course. Global Perspectives on Accounting Education, 3: 49-66.

23. Trank, C. Q. and S. Rynes. (2003) Who moved our cheese? Reclaiming professionalism in business education, Academy of Management Learning and Education, 2(2), pp. 189-205.

24. Waddock, S. (2005) Hollow men and women at the helm . . . hollow accounting ethics, Issues in Accounting Education, 20(2), pp. 145-150.

25. Windsor, D. (2002) An open letter on business school responsibility (8 October). Available at http://info.cba.ksu.edu/swanson/Call/Call.pdf (accessed 15 May 2006). 


\section{NOTES}

